\title{
Designing strategy for improving teacher's organizational commitment in the remote elementary schools of Merauke district, Papua, Indonesia
}

\author{
Werang, Basilius Redan \\ Universitas Musamus Merauke, Indonesia (erna0405@yahoo.co.id; lirang267@yahoo.co.id) \\ Pure, Ermelinda Agnes Gunu \\ Universitas Musamus Merauke, Indonesia (agnesermelinda@yahoo.co.id)
}

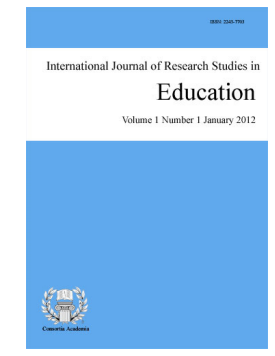

ISSN: 2243-7703 Online ISSN: 2243-7711

OPEN ACCESS

Received: 30 November 2016

Revised: 21 December 2016

Available Online: 29 January 2017 DOI: $10.5861 /$ ijrse.2017.1702

Accepted: 18 January 2017

\begin{abstract}
Teacher's organizational commitment is one of the basic concepts unfolding the relationship between an employee and an organization. As the success of an organization may depend on how its employees get committed to, this present study was aimed at designing strategic policies to boost teacher's organizational commitment in the remote elementary schools of Merauke district, Papua, Indonesia. This present study employed a qualitative research approach using a case study research design due to that: (a) our personal competence of securing the informants' real name and office that may cause any harm to their carrier and personality, (b) our focus is on the effort of creating strategic policies to address teacher's organizational commitment in the remote elementary schools of Merauke district, Papua, and (c) we can utilize data of teacher's organizational commitment from the vary of data resources, namely: local community members, educational practitioners (teachers, lecturers, school principals, school supervisors), and local government. A purposive sampling technique was used to obtain 72 informants drawn from amongst local community members, educational practitioners (teachers, lecturers, school principals, and school supervisors), and local government. Profound interview to the local community members, educational practitioners (teachers, lecturers, school principals, and school supervisors), and local government was the main tool of the study to collect data. Data were analyzed qualitatively using Ishikawa's fishbone diagram analysis. Results of data analysis revealed three major strategic policies of boosting teacher's organizational commitment in the remote elementary schools of Merauke district, namely: (a) strategies related to teachers' individual characteristics, (b) strategies related to teachers' working conditions, and (c) strategies related to educational policy maker. These findings might be imperative for the institution of teacher training and education to design curriculum to address the special need of having teachers which are morally and mentally qualified. These findings might be also worthwhile for the local government to make an effort of creating more enjoyable working conditions and of creating regulations that will practically guide the way of recruiting and of selecting the school principals.
\end{abstract}

Keywords: teacher; organizational commitment; elementary schools; remote area; Merauke district 


\section{Designing strategy for improving teacher's organizational commitment in the remote elementary schools of Merauke district, Papua, Indonesia}

\section{Introduction}

Teaching profession is a great responsibility than a mere job and, therefore, those who are willing to enter the teaching profession have to set and to fit themselves with such required responsibilities. Teacher's organizational commitment is one of the basic concepts unfolding the relationship between a teacher and his or her school. Teacher attendance reflects teacher's commitment of how to get student success. Werang, Betaubun, and Pure (2015) reported that one in three remote elementary school teachers of Merauke district were not at school at the time of visit.

There are vary of studies have been conducted on teachers organizational commitment (e.g. Kadyschuk, 1997; Bogler \& Somech, 2004; Crosswell, 2006; Dee, Henkin, \& Singleton, 2006; William, 2011; Devos \& Tuytens, 2013; Garipaĝaogiu, 2013; Hamid, Nordin, Adnan, \& Sirun, 2013; Ayale, 2014; Mousa \& Alas, 2016). Lack of study on teachers' organizational commitment in Merauke district makes this present study robust. Since Uncen, Unipa, Smeru, BPS, and Unicef's (2012) study revealed a positive correlation between teachers attendance and student academic achievement, getting teachers to attend the school may help remote elementary schools of Merauke district achieve the improvement in students' academic achievement, especially in reading, writing, and arithmetic.

As the success of schools may depend on how teachers get committed to, this present study was aimed at designing strategic policies to boost teachers' organizational commitment in the remote elementary schools of Merauke district, Papua, Indonesia. Profound interview to 72 informants drawn from amongst local community members, practitioners (teachers, lecturers, school principals, school supervisors), and local government was the main tool of data collection. To design strategic policies in boosting teachers' organizational commitment in the elementary schools of Merauke district, we employed qualitative data analysis using Focus Group Discussion (FGD), which we briefly explain below.

\section{Review of related literature}

\subsection{Defining Teacher's Organizational Commitment}

Organizational commitment has attracted considerable interest in an attempt to understand and clarify the intensity and stability of employee's dedication to an organization (Lumley, 2010). Hall, Schneider, and Nygren (1970) defined organizational commitment as the process by which the goals of the organization and those of the individual become increasingly integrated and congruent. Meanwhile Porter, Steers, Mowday, and Boulian (1977) viewed organizational commitment in terms of the strength of an individual's identification with and involvement in a particular organization. Whereas, Mowday, Steers, and Porter (1982) defined organizational commitment as the relative strength of an individual's identification with and involvement in a particular organization. Similarly, Allen and Meyer (1990) regarded organizational commitment as a psychological connection that individuals have with their organization, characterized by strong identification with the organization and a desire to contribute to the accomplishment of organizational goals. Based on these opinions, organizational commitment can be defined as an employee's willingness to involve in and to be the part of a particular organization which is seen as his or her investment over time.

Organizational commitment is a multi-dimensional construct (Meyer, Allen, \& Smith, 1993). Meyer and Allen (1991) conceived of organizational commitment as reflecting three core themes, that are affective, 
Designing strategy for improving teacher's organizational commitment in the remote elementary schools

continuance, and normative. Each of these components has ramifications for the organization with respect to employee absenteeism and retention. Firstly, affective commitment; according to Meyer et al. (1993), affective commitment is employee's emotional attachment to, identification with and involvement in the organization. Affective commitment identifies employees who stay with the organization because they want to. To the Meyer and Allen's (1997) opinion, Wolowska (2014) wrote as follows:

In the model discussed, the main process which leads to the development of affective commitment is an individual's personal satisfaction which has its source in satisfying personal needs, meeting expectations as well as achieving individual goals through the mediation of the organization. This experiencing of particular satisfaction may be also connected with the sense of support received, the sense of organizational justice as well with the feeling of workplace meaningfulness and own contribution to the organization functioning. Therefore, work environment which supports its employees, treats them well and positively appraises their results, contributes to their stronger feeling of self-esteem (p. 131).

Secondly, continuance commitment; Muray et al. (as cited in Ismail, 2012) regarded continuance commitment as the counterpart of affective commitment. "Continuance commitment is the idea that individuals do not leave a company for fear of losing their benefits, taking a pay cut, and not being able to find another job" (Ismail, 2012). While Buitendach and de Witte (2005 as cited in Werang \& Pure, 2015) referred to as the cost that the employee links with leaving the organization or on a perceived lack of alternative employment opportunities. To the Meyer and Allen's (1997) opinion, Marmaya, Hitam, Zawawi, and Jody (2011) wrote as follows:

Continuance commitment develops out of the perceived cost (benefit against loss) and requires that the employee be aware of these benefits or losses. Therefore, different workers who encounter identical situation may experience different level of continuance commitment (pp. 185-186).

Thirdly, normative commitment; Meyer and Allen (1997) defined normative commitment as a feeling of obligation to continue employment, while Marsh and Mannari (1997) viewed normative commitment as the commitment employees consider morally right to stay in a particular organization, regardless of how much status enhancement or satisfaction the organization gives him or her over the years. Whereas, Wolowska $(2014$, p. 130) regarded normative component as "the sense of moral study to stay in the organization. Employees with high level of normative commitment feel that they ought to do so". To the Meyer and Allen's (1997) opinion, Wolowska (2014) wrote as follows:

Normative organizational commitment develops on previous socialization experience (pressure from the family and culture) as well as on the influence the individual is subject to as a newly-employed person in the organization during the socialization process. Socialization experience, both from an individual's early childhood period and the one acquired in the place of work, include a lot of various information connected with the relevance of particular attitudes and behavior. Complex conditioning and modeling processes teach individuals and provide them with knowledge on what is valuable, what their family, culture or organization expect from them. In the case of normative commitment the belief that it is proper to be loyal towards one organization becomes internalized (p. 131).

Teacher's organizational commitment might be high or low. High committed teacher usually performs the following: (a) apetite for new challenges: high committed teacher is always looking for new challenges. They are thirsty for knowledge and skills and are more happy at schools that allow them to quench that thirst; (b) problem solving attitude: whatever obstacle may come, high committed teachers are prepared to seek way to overcome it even without any direction from the school principal; (c) willingness to lead: high committed teacher does not need much direction from the school principal because they have already known what tasks should be carried out 
and how to carry out the such tasks to the best possible standard, and come up with their own ways to solve emergencies and crisis within the school; (d) job and career satisfaction: high committed teacher tends to feel satisfied with their job and career; and (e) greater performance: high committed teacher does everything better than what are required (Webrecruit Ireland, 2015). On the contrary, low committed teacher may create difficulties and cause the deviations in respect to the educational aims of the school. Low committed teacher usually performs the following attitudes: (a) showing less interest in advancement; (b) seeming less interested in pleasing their boss then before; (c) acting reluctant to commit to long-term projects; and (d) doing the minimum amount of work needed (The KMA Team, 2014).

Based on the above definitions, teacher's organizational commitment refers to teacher's perception of and identification with the organization in which he or she belongs. Teacher's way of percepting the organization may influence the way of his or her identification with that organization. We do believe, a teacher may be gladly identify his or herself with the organization in which his or her rights are met adequately and, then, involves strongly contributing for the attainment of the organization's goals.

\subsection{Determinants of Teacher's Organizational Commitment}

Teacher's organizational commitment is of crucial for organizational effectiveness (Dee et al., 2006) and, therefore, it is important to identify the determinant factors of teacher's commitment to the school. Vary of studies have been conducted to examine what factors determine teacher's organizational commitment. Some scholars argued that teachers' organizational commitment is mainly affected by principal leadership (e.g. Hoy, Tarter, \& Bliss, 1990; Koh, Steers, \& Terborg, 1995; Nguni, Sleegers, \& Denessen, 2006). Littrel and Billingsley (1994) and Singh and Billingsley (1998) indicated that supportive leadership, which is related to the leaders' role in fostering and setting a collective school vision and clear goals, motivating and helping teachers, stimulating teachers' professional learning, is likely to have a positive effect on teachers' organizational commitment. Rosenholtz (1989) and Louis (1998) suggested that teachers are more committed to the school when principals offer feedback, encouragement, and acknowledgement. While Ebmeier (2003) and Somech (2005) indicated that supervisory leadership, which is characterized by monitoring and supervising teacher, is closely related to teachers' organizational commitment.

Other scholars argued that teacher's organizational commitment is affected by teachers' individual characteristics, such as age and gender. Many studies (e.g. Sheldon, 1971; Hrebiniak \& Alluto, 1972; Steers, 1977; Stevens, Beyer, \& Trice, 1978; Angle \& Perry, 1981; Morris \& Sherman, 1981, Mathieu \& Zajac, 1990) claimed that age is positively related to commitment level. For example, Mathieu and Zajac (1990, p. 177) suggested that older workers become more attitudinally committed to an organization for a variety of reasons, including greater satisfaction with their jobs, having recieved better positions, and having 'cognitively justified' their remaining in an organization. Other studies (e.g. Mathieu \& Zajac, 1990; Bar-Hayim \& Bermann, 1992; Cohen, 1992) asserted that gender differences may influence organizational commitment. Mathieu and Zajac (1990, p. 177) found that women tended to be more organizationally committed than men, whereas Cohen (1992) found that among blue collars workers, females were more committed to the organization, while among white collar professionals, male were more committed.

In Indonesia context, our previous study (Werang et al., 2015) revealed four main categories of factors influencing low level of teachers' organizational commitment in the remote elementary schools of Merauke district, Papua, namely: (a) school principal such as lack of leadership capabilities and of teaching motivation, (b) teachers' individual characteristics which comprised of teachers' job satisfaction and teachers' marital status, (c) teachers' working conditions which comprised of inadequate school physical facilities such as unavailability of school housings and of teaching-learning facilities, high cost of transportation and of living in the remote area, and (d) local government policy of assigning spouses teachers in the different area which is far apart and of appointing school principal based on the interest of the local authorities. 
Based on the above findings, determinant factors of teachers' organizational commitment could be summarized as follows: [a] principal leadership both supportive leadership (e.g. fostering and setting a collective school vision and clear goals, motivating and helping teachers, stimulating teachers' professional learning) and supervisory leadership (e.g. monitoring and supervising teacher); $[\mathrm{b}]$ teachers' individual characteristics and behavior such as age, gender, marital status, and job satisfaction; [c] teachers' working conditions such as school physical supporting facilities (e.g. school housings, teaching-learning facilities, high cost of transportation and of living in the remote area); and [d] local government policy of assigning teachers and of appointing school principals.

\subsection{Analytical Framework of the Study}

Based on the Merauke district academic thinking and related literatures examining the strategies for boosting teachers' organizational commitment in the remote elementary schools of Merauke district, the analytical framework of this present study is as presented in Figure 1.

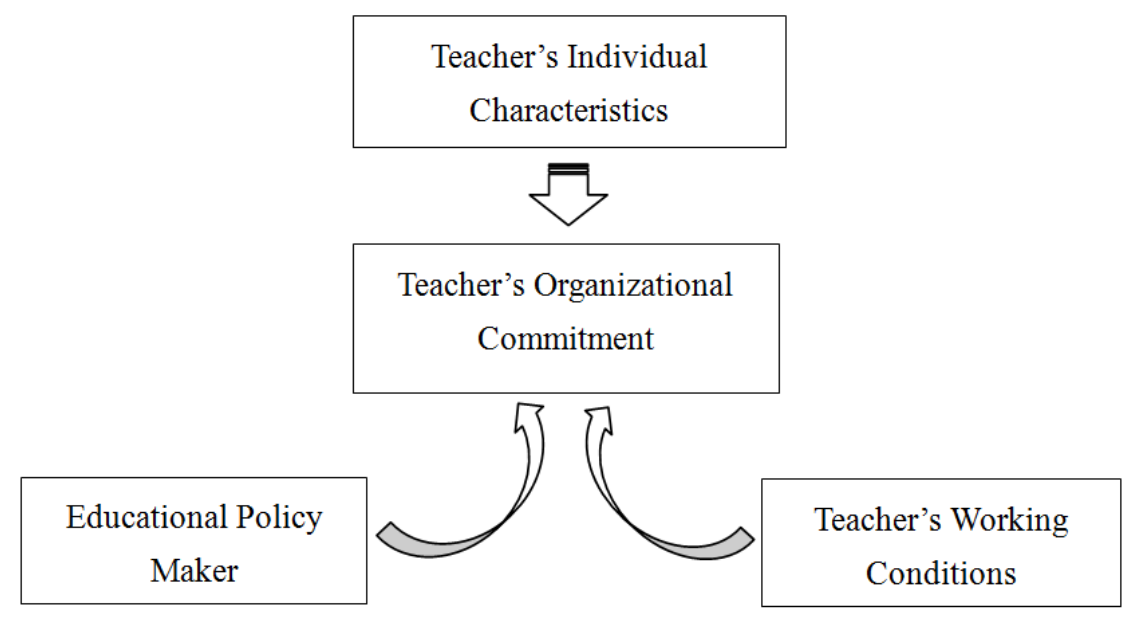

Figure 1. Analytical framework of the study

\section{Methodology}

This study dealt with the question of what are the strategies that could improve teacher organizational commitment in the remote elementary schools of Merauke district, Papua, Indonesia? Since this study is concerned with the effort of boosting teacher's organizational commitment, the proper study design to handle the issue was a qualitative design using a case-study method. We employed a qualitative research approach using a case study research design due to that: (a) our personal competence of securing the informants' real name and office that may cause any harm to their carrier and personality, (b) our focus is on the contemporary phenomenon only, that is teachers absenteeism in the remote elementary schools of southern Papua, Indonesia; and (c) we can utilize data of teachers absenteeism from the vary of data resources, namely: teachers, school principals, and local community members.

Merauke district comprised of 20 sub-districts with the total population of 213,484 . There are 203 elementary schools with the total number of teachers are 1300 (see Table 1). Data were collected from April 2016 to October 2016 due to limited research personnel. Profound interview to the teachers, elementary school principals, and local community members of respective schools was the main tool of the study to collect data. A purposive sampling technique was used to obtain 72 informants drawn from amongst local community members (LCM $=35$ informants), teachers $(\mathrm{T}=26$ informants), school principals ( $\mathrm{SP}=4$ informants), and school supervisors ( $\mathrm{SS}=2$ informants), and local authorities (LA = 5 informants) of 12 remote elementary schools of Merauke district. Participants were given a code based on the date of collecting data. 
Werang, B. R., \& Pure, E. A. G.

\section{Table 1}

Geographical and Demographical Details of Merauke District Area

\begin{tabular}{|c|c|c|c|c|}
\hline Sub-District & Area $(\mathrm{Km})$ & Population & Elementary Schools & Teachers \\
\hline Kimaam & $4,630.30$ & 6,214 & 8 & 52 \\
\hline Waan & $2,868.06$ & 4,804 & 8 & 28 \\
\hline Tabonji & $5,416.84$ & 5,485 & 6 & 24 \\
\hline Ilwayab & $1,999.08$ & 5,480 & 5 & 31 \\
\hline Okaba & $1,560.50$ & 5,232 & 11 & 72 \\
\hline Tubang & $2,781.18$ & 2,397 & 6 & 31 \\
\hline Ngguti & $3,554.62$ & 2,007 & 7 & 38 \\
\hline Kaptel & $2,384.05$ & 1,861 & 5 & 22 \\
\hline Kurik & 977.05 & 14,270 & 12 & 73 \\
\hline Animha & $1,465.60$ & 9,530 & 5 & 29 \\
\hline Malind & 490.60 & 2,083 & 7 & 37 \\
\hline Merauke & $1,445.63$ & 95,562 & 36 & 367 \\
\hline Naukenjerai & 905.86 & 13,878 & 5 & 22 \\
\hline Semangga & 326.95 & 18,183 & 11 & 68 \\
\hline Tanah Miring & $1,516.67$ & 7,494 & 16 & 96 \\
\hline Jagebob & $1,364.96$ & 3,114 & 14 & 79 \\
\hline Sota & $2,843.21$ & 2,009 & 6 & 27 \\
\hline Muting & $3,501.67$ & 5,469 & 12 & 72 \\
\hline Eligobel & $1,666.23$ & 4,053 & 12 & 66 \\
\hline Ulilin & $5,092.57$ & 4,359 & 11 & 64 \\
\hline Total & $46,791.63$ & 213,484 & 203 & 1300 \\
\hline
\end{tabular}

Source. The Central Bureau of Statistics of Merauke District, 2014 (with modification).

To validate data, we employed triangulation (by interviewing the same informant on two different occasions) and member check by conducting FGD with the involvement of the informants' representative. We conducted data analysis qualitatively using Ishikawa's fishbone analysis (WBI Evaluation Group, 2007) due to that: (a) fishbone analysis permit a thoughtful analysis that avoids overlooking any possible root causes for a need; (b) the fishbone technique is easy to implement and creates an easy-to-understand visual representation of the causes, categories of the causes and the need; and (c) by using fishbone analysis, we were able to focus our attention to all possible causes or factors influencing teachers absenteeism in the remote elementary schools of southern Papua, Indonesia (see Figure 2).

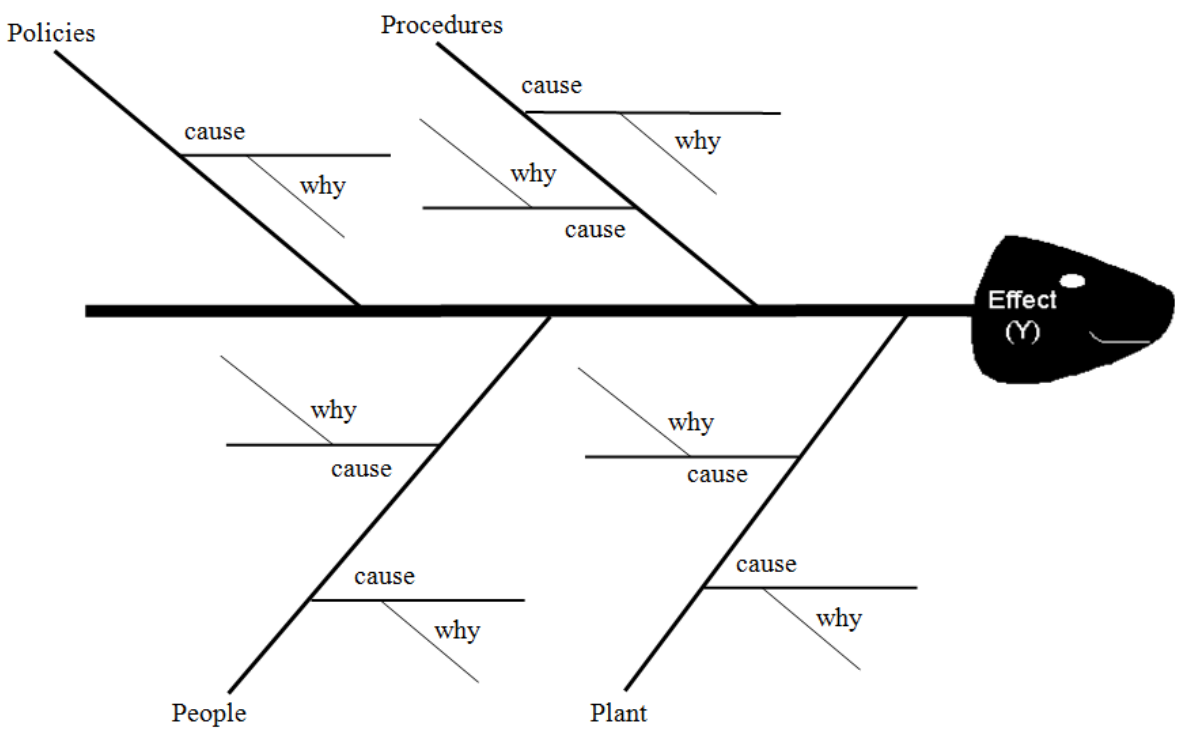

Figure 2. Ishikawa's Fishbone Analysis Diagram

(Source. WBI Evaluation Group, 2007, with modification) 


\section{Results}

Strategies found to be adequately boosting teachers' organizational commitment in the remote elementary schools of Merauke district are follows:

4.1 Teachers' perception of the strategies of boosting teachers organizational commitment:

$>$ Building well-equipped school housing for teachers.

$>$ Breaking the remoteness by providing public transportation.

$>\quad$ The appointment of school principal should not be based of the political interest of local authorities.

$>$ Spouses teachers should not be assigned in the different working areas which are far apart.

$>$ School principal's appointment should be based on the competency he or she has.

$>\quad$ Provide ICT and electricity facilities for teachers to upgrade knowledge and skills of teaching.

$>$ Improving local community ties.

$>$ Improving parental involvement in child(ren) education.

$>\quad$ Improving parental awareness on the importance of child(ren) education.

4.2 Local Community's perception of the strategies of boosting teachers organizational commitment:

$>$ Delaying payment of wage.

$>$ Dismissal.

$>\quad$ Building healthy and well-equipped school housing for teachers.

$>\quad$ Breaking the remoteness by providing public transportation.

$>$ Teachers' recruitment should be based first on the passion and moral disposition.

$>\quad$ Teachers' candidate should be well educated and trained.

$>\quad$ Regular monitoring.

4.3 Principals' perception of the strategies of boosting teachers organizational commitment:

$>\quad$ Regular monitoring

$>\quad$ Building healthy and well-equipped school housing for teachers.

$>$ Spouses teachers should not be assigned in the different working areas which are far apart.

$>\quad$ Provide IT and electricity facilities for teachers to upgrade knowledge and skills of teaching.

4.4 School supervisors' perception of the strategies of boosting teachers organizational commitment:

$>\quad$ Provide sufficient funds for regular monitoring.

$>$ Spouses teachers should not be assigned in the different working areas which are far apart.

$>\quad$ Building healthy and well-equipped school housing for teachers. 
Werang, B. R., \& Pure, E. A. G.

4.5 Authorities' perception of the alternative strategies of boosting teachers organizational commitment:

$>$ Delaying payment of wage.

$>$ Dismissal.

We started data analysis with an effort of reducing data which are not relevant to the topic. To display data we employed Ishikawa's fishbone analysis. In order that data were categorized well under the Ishikawa's causes and effects diagram, we grouped the data into three main categories as follows. Firstly, alternative strategies related to the teachers' individual characteristics which comprised of (a) reinforcing teachers' basic formation, (b) improving teachers' welfare, (c) creating moral standards for teachers' recruitment, (d) teachers' ongoing formation, and (e) assigning spouses teachers in the same working area. Secondly, strategies related to the teachers' working conditions which comprised of: (a) breaking the remoteness by providing transportation and ICT facilities, (b) providing adequate school physical facilities, such as school housings and teaching learning facilities, (c) empowering school principal's roles and capabilities through leadership training and creating high standards for principal's recruitment and selecting, (d) improving parents' awareness on the importance of education and of their involvement in the school's life through socialization and accompaniment. Thirdly, strategies related to the educational policy maker which comprised of (a) building finance policy for regular monitoring, (b) strengthening management at the level of Education Office, (c) creating standards for school principal's recruitment, selection, and appointment, (d) delaying payment of wage for teachers who do not teach regularly, and (e) dismissal. The results of data analysis are displayed in Figure 3.

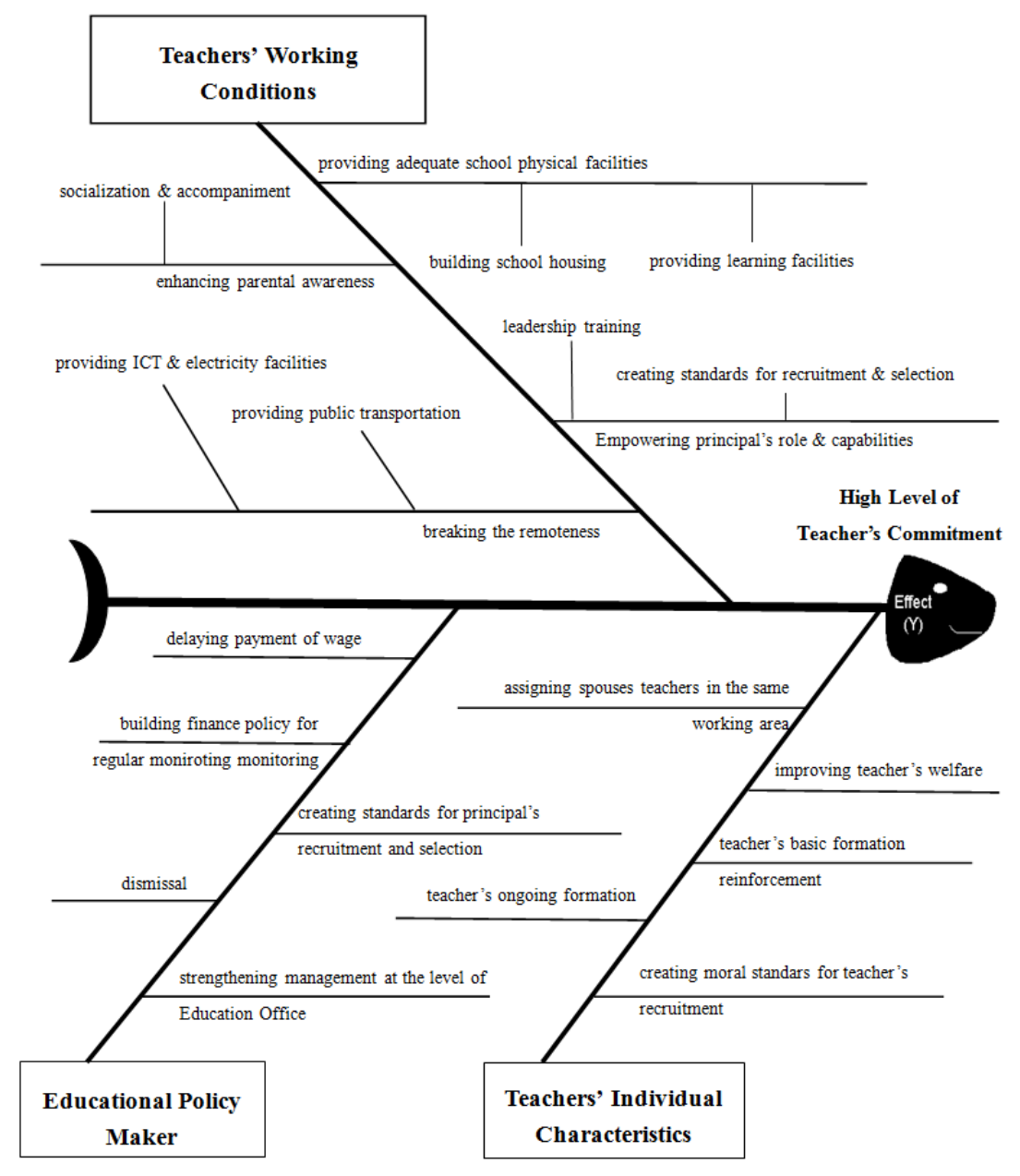

Figure 3. Strategies for improving teacher's organizational commitment in the remote elementary schools of Merauke district, Papua, Indonesia 


\section{Discussions}

\subsection{Teacher's Individual Charateristics}

The strength of teaching profession might depend upon the degree of commitment of teachers. In the context of teacher's individual characteristics, Fox (1964, pp. 19-20) pointed out at least four characteristics of committed teachers. Firstly, committed teacher desires to be a good teacher. Fox (1994) noted 'the desire of being a good teacher' as of the most important characteristics of committed teacher. Further, Fox (1994) stated as follows,

The committed teacher [...] wants to teach and he wants to do this well. [...] The committed teacher enjoys working with children and youth and has a strong desire to help each person develop his full potential. He enjoys his work as a teacher; and his students, his colleagues, and the member of the community knows that he enjoys teaching (p. 19).

Unfortunately, our previous study in the remote elementary schools of Merauke regency revealed that one in three teachers is not at school at the time of visit. They are heading for urban area for more enjoyable activities. In order to waive that a pity condition, in this study we offer teacher's basic formation reinforcement and the need of moral standards for teacher's recruitment as the strategies to improve teacher's commitment to the teaching profession.

Secondly, committed teacher is more than a purfeyor of fact. Nemo dat quod non habet, thus Latin proverb. It means that 'nobody can not give what he or she has not'. This proverb assumes that one must have something to teach before he or she can teach. The committed teacher always realizes that education is more than an accumulation of factual informations that he or she has had (Fox, 1994, p. 19). As teacher does not finish learning with his or her graduation, the teacher should be a selector of knowledge and skills in our rapidly changing society. Rahman et al. (2011 as cited in Werang, 2014) argued that if teacher fails to keep himself or herself in touch with the rapid changing in human knowledge which offers new approaches and new methods of teaching, he or she is proving himself or herself as an inefficient and ineffective. In this context of view, teacher ongoing formation is one of the strategies to enhance teacher's commitment to the teaching profesion.

Thirdly, committed teacher recognizes and accepts the worth of each individuals. The teacher commits to the worth of each individual means that he or she is realy concerned to the total development of his or her students. The committed teacher recognizes that students are vary in socioeconomic (SES) background, size, color, and motivation, and he or she attempts to provide for such differences (Fox, 1964, p. 20). Teachers who go away from the teaching of any knowledge, skilss, and values are doing disservice to the education of all educable youth. To help teacher to not go way from his or her obligation of teaching, in this present study we offer 'improving teacher's welfare and 'assigning spouses teachers in the same working area' as the strategies of improving teacher's commitment to the teaching profession.

Fourthly, committed teacher fulfills his or her personal responsibilities. Teachers are regarded by the society as gatekeepers to knowledge and mentors with an important role to develop child(ren)'s character (Suparno, 2008 as cited in Uncen-Unipa-Smeru-BPS-Unicef, 2012, p. 22). Regarding teacher's role of developing students' character inside and outside of the classroom, Lumpkin (2008, p. 45, 49) stated,

Teachers should educate for character, especially through teaching respect and responsibility. [...] Teachers with character serve as role models for telling the truth, respecting others, accepting and fulfilling responsibilities, playing fair, earning and returning trust, and living a moral life. They should model the importance of engaging in lifelong quest to do the harder right, rather than the easier wrong. Teachers with character teach their students that individuals make morally principled decisions through the moral-reasoning process. They can help their students 
Koenig (2014, p. 1) argued that teachers are entrusted with the responsibility to educate the future productive citizens of tomorrow to contribute to the boarder well-being of a society. Teachers are even obliged to perform well many different roles and responsibilities, such as being a motivator, observer, counsellor, manager, school leader, resource provider, mentor for fellow teachers, and an active agent of change for themselves and their students. In this respect, we offer 'improving teacher's welfare' and 'teachers ongoing formation' as the alternative strategies of improving teacher's commitment to the profession, school, students, and teaching activities in order that the effectiveness of school is met adequately.

\subsection{Teacher's Working Conditions}

The committed teacher recognizes well his professional tasks and responsibilities to students, parents, colleagues, school principal, educational administrator, and the local community. As a teacher he or she is obliged to accept his or her professional tasks of teaching, educating, and training the students. As a teacher he or she is also obliged to accept his or her professional responsibilities of advancing the cause of education, improving the quality of teaching, promoting the welfare of teachers, and elevating the status of the profession (Fox, 1994; Werang, 2010).

Teaching is a very exhausted and stressful profession especially for those teachers who work in remote areas. In this context of view, having an attractive and enjoyable workplace is a key to boost teacher's organizational commitment and schools success alike. Our previous study (Werang, Leba, \& Pure, 2016) revealed that teachers in the remote areas may spend more time away from their schools due to that: (a) remoteness with regards to high cost of living due to the logistical difficulties transportation and the absence of public transportation to access school, (b) school physical facilities with regards to the inavailability of school housing and of teaching-learning facilities, (c) principal leadership with regards to the lack of principal's competence due to the local authority's policy of appointing school principal based on the political interest, and (d) the unawareness of local community on the importance of education for child(ren)'s future life.

Teacher is still man or woman who, just like other employees, likely to feel more committed in a more comfortable workplace. To create a more comfortable place for teachers, our present study offer 4 alternative strategies to improve teacher's commitment to the teaching profession as follows: (a) breaking the remoteness through providing public transportation and ICT facilities; (b) empowering principal's role and capabilities as agent of change through regular training and creating standards for the recruitment and selecting of school principal; (c) providing school physical facilities through building well-equipped school housing and providing teaching-learning facilities; and (d) improving parental awareness on the importance of child(ren)'s education through regular socialization and accompaniment.

\subsection{Educational Policy Maker}

Since the education of the young people is calling for the active involvement of the government to maintain the school facilities and to provide teachers with instructional resources and educational policies, the role of local government is one of the most important components to school success. In the context of Papua, Indonesia, this role seems to be a privilege for the local government since it has been given the pivotal rights of recruiting, selecting, and assigning both teachers and the school principals. Unfortunately, this privilege are often abused for political interest of the local authorities. Local authorities may have their own perception on how teachers and the school principals are assigned but our previous study (Werang et al., 2016) revealed of that matter.

Our previous study (Werang et al., 2015) revealed that local authority's educational policy is one of the factors responsible for the low level of teacher organizational commitment in the remote elementary schools of Merauke regency, Papua. In this context of view, in this present study we offer the following strategies for 
Designing strategy for improving teacher's organizational commitment in the remote elementary schools

boosting teacher's commitment to the teaching profession: (a) delaying payment of wage; (b) strengthening educational management at the level of Education Office; (c) creating standards for principal recruitment and selection; (d) building finance policy for regular monitoring; and (d) dismissal.

\section{Conclusions, Implications, and Recomendation}

Our study's findings indicate that high teachers' commitment to the work of teaching in the remote elementary schools of Merauke district, Papua, is predicted by three main categories of strategies as follows:

> Strategies related to teachers characteristics: reinforcing teachers' basic formation, creating standards for teacher recruitment, improving teachers' welfare, teachers' ongoing formation, and assigning spouses teachers in the same working area.

$>$ Strategies related to teacher's working conditions: breaking the remoteness, improving parental awareness on the importance of education, providing school physical facilities, and empowering principal's role and capabilities.

$>\quad$ Strategies related to educational policy maker: strengthening management at the Office of Education, building finance policy for regular monitoring, delaying payment of wage, creating standards for principal recruitment and selection, and dismissal.

Practical implication of our findings is that teachers' organizational commitment in the remote elementary schools of Merauke district, Papua, would only be improved if all the above designed strategies are seriously and well implemented by all the interest parties, such as local government and the institution of teacher training and education. Based on the findings, it might be imperative for: (a) the institution of teacher training and education to design specific curriculum to address the special need of having teachers which are morally and mentally qualified, and (b) the local government to make an effort of creating more enjoyable working conditions and of creating regulations that will practically guide the way of recruiting and of selecting the teachers and the school principals alike.

The present study reveals something new that might not be found in the previous study. Therefore, findings of our study may theoretically add the existing literature on the strategies of boosting teachers' organizational commitment. Since our study is limited on the view of designing strategies to boost teacher's organizational commitment in the remote elementary schools of Merauke district, Papua, a deeply and widely study on this topic is fully recommended.

Acknowledgement: We are grateful for the support of Director of Research and Community Service of Research, Technology, and Higher Education in Jakarta who has funded all the process of the study. We would like to thank for all the informants and the participants of FGD who have contributed in a special way to the study. We are pleased to acknowledge the Commitee of 2nd International Conference on Education and Training who have invited us to present this research paper at the conference. No words are sufficient to express the deeply gratitude we have for all of them.

\section{References}

Allen, N., \& Meyer, J. (1990). The measurement and antecedents of affective, continuance and normative commitment to the organization. Journal of Occupational Psychology, 63, 1-8. https://doi.org/10.1111/j.2044-8325.1990.tb00506.x

Angle, H. L., \& Perry, J. L. (1981). An empirical assessment of organizational commitment and organizational effectiveness. Administrative Science Quarterly, 26, 1-13. https://doi.org/10.2307/2392596

Ayale, D. (2014). Teachers' job satisfaction and commitment in general secondary schools of Hadiya Zone, in 
southern nation nationality and people of regional state (Unpublished masteral thesis). Department of Educational Planning and Management, Jimma University.

Bar-Hayim, A., \& Bermann, G. S. (1992). The dimensions of organizational commitment. Journal of Organizational Behavior, 13, 379-387. https://doi.org/10.1002/job.4030130406

Bogler, R., \& Somech, A. (2004). Influence of teacher empowerment on teachers' organizational commitment, professional commitment and organizational citizenship behavior in schools. Teaching and Teacher Education, 20, 277-289. https://doi.org/10.1016/j.tate.2004.02.003

Coetzee, M., Schreuder, A. M. G., \& Tladinyane, R. (2007). Organizational commitment and its relation to career anchors. Southern African Business Review, 11(1), 65-68.

Cohen, A. (1992). Antecedents of organizational commitment across occupational groups: A meta-analysis. Journal of Organizational Behavior, 13, 539-558. https://doi.org/10.1002/job.4030130602

Crosswell, L. (2006). Understanding teacher commitment in times of changes (Unpublished doctoral dissertation). Faculty of Education, Queensland University of Technology.

Dee, J. R., Henkin, A. B., \& Singleton, C. A. (2006). Organizational commitment of teachers in urban schools: Examining the effects of team structures. Urban Education, 41, 603-627. https://doi.org/10.1177/0042085906292512

Devos, G., Tuytens, M., \& Hulpia, H. (2013). Teacher organizational commitment: Examining the mediating effect of distributed leadership. American Journal of Education, 120(2), 205-231. https://doi.org/10.1086/674370

Ebmeier, H. (2003). How supervision influences teacher efficacy and commitment: An investigation of a path model. Journal of Curriculum and Supervision, 18, 110-141.

Fox, R. B. (1994). The “committed” teacher. Retrieved from http://www.ascd.org/ASCD/pdf/journals/ed_lead/el_196410_fox.pdf

Garipaĝaoĝiu, B. C. (2013). Examining organizational commitment of private school teachers. Journal of Educational and Instructional Studies in the World, 3(2), 22-28.

Hall, D. T., Schneider, B., \& Nygren, H. T. (1970). Personal factors in organizational identification. Administrative Science Quarterly, 15, 176-190. https://doi.org/10.2307/2391488

Hamid, S. F., Nordin, N., Adnan, A. A., \& Sirun, N. (2013). A study on primary school teachers' organizational commitment and psychological empowerment in the district of Klang. Procedia-Social and Behavioral Sciences, 90, 782-787. https://doi.org/10.1016/j.sbspro.2013.07.152

Hoy, W. K., Tarter, C. J., \& Bliss, J. R. (1990). Organizational climate, school health, and effectiveness: A comparative analysis. Educational Administration Quarterly, 26, 260-279. https://doi.org/10.1177/0013161X90026003004

Hrebiniak, L. G., \& Alluto, J. A. (1972). Personal and role-related factors in the development of organizational commitment. Administrative Science Quarterly, 17, 555-572. https://doi.org/10.2307/2393833

Huselid, M. A., \& Day, N. E. (1991). Organizational commitment, job involvement, and turnover. A substantive and methodological analysis. Journal of Applied Psychology, 76(3), 380-391. https://doi.org/10.1037/0021-9010.76.3.380

Ismail, (2012). Organizational commitment and job satisfaction among staff of higher learning education institutions in Kelantan (Unpublished masteral thesis). Universiti Utara Malaysia.

Jans, N. A. (1989). Organizational commitment, career factors and career/life stage. Journal of Organizational Behavior, 10, 247-266. https://doi.org/10.1002/job.4030100305

Kadyschuk, R. (1997). Teacher commitment: a study of the organizational commitment, professional commitment and union commitment of teachers in public schools in Saskatchewan (Unpublished doctoral dissertation). College of Graduate Studies and Research, University of Saskatchewan, Saskatoon.

Koenig, A. (2014). Learning to prevent burning and fatigue: Teacher burnout and compassion fatigue. Electronic Thesis and Dissertation Respitory, Paper 1928.

Koh, W. L., Steers, R. M., \& Terborg, J. R. (1995). The effect of transformational leadership on teacher attitude and student performance in Singapore. Journal of Organizational Behavior, 16, 319-333. 
Designing strategy for improving teacher's organizational commitment in the remote elementary schools https://doi.org/10.1002/job.4030160404

Littrell, P., \& Billingsley, B. S. (1994). The effect of principal support on special and general educators' stress, job satisfaction, school commitment, health, and intent to stay in teaching. Remedial and Special Education, 15, 297-311. https://doi.org/10.1177/074193259401500505

Louis, K. S. (1998). Effect of teacher quality of work life in secondary schools on commitment and sense of efficacy. School Effectiveness and School Improvement, 9, 1-27. https://doi.org/10.1080/0924345980090101

Lumley, E. (2010). Exploring the relationship between career anchors, job satisfaction and organizational commitment (Unpublished doctoral dissertation). Department of Industrial and Organizational Psychology, University of South Africa.

Lumpkin, A. (2008). Teachers as role models teaching character and moral virtues. Jopero, 79(2), 45-49. https://doi.org/10.1080/07303084.2008.10598134

Marmaya, N. H. B., Hitam, M., Zawawi, N., \& Jody, J. M. (2011). Organizational commitment and job burnout among employees in Malaysia. Retrieved from http://www.ipedr.com/vol1/40-B10039.pdf

Marsh, R., \& Mannari, H. (1977). Organizational commitment and turnover: A prediction study. Administrative Science Quarterly, 22, 57-67. https://doi.org/10.2307/2391746

Mathieu, J. E., \& Sajac, D. M. (1990). A review and meta-analysis of the antecedents, correlates, and consequences of organizational commitment. Psychological Bulletin, 108, 171-194. https://doi.org/10.1037/0033-2909.108.2.171

Meyer, J., \& Allen, N. (1991). A three component conceptualization of organizational commitment. Human Resources Management Review, 1, 61-89. https://doi.org/10.1016/1053-4822(91)90011-Z

Meyer, J., \& Allen, N. (1997). Commitment in the workplace: Theory, research and application. London: Sage.

Meyer, J., Allen, N., \& Smith, C. (1993). Commitment to organizations and occupations: Extension and test of a three-component conceptualization. Journal of Applied Psychology, 78(4), 538-551. https://doi.org/10.1037/0021-9010.78.4.538

Morris, J. H., \& Sherman, J. D. (1981). Generalizability of an organizational commitment model. Academy of Management Journal, 24(3), 512-526. https://doi.org/10.2307/255572

Mousa, M., \& Alas, R. (2016). Workplace spirituality and organizational commitment: A study on the public school teachers in Menoufia (Egypt). African Journal of Management, 10(10), 247-255. https://doi.org/10.5897/AJBM2016.8031

Mowday, R., Steers, R., \& Porter, L. (1982). Employee-organization linkages: The psychology of commitment, absenteeism, and turnover. New York: Academic Press.

Nguni, S., Sleegers, P., \& Denessen, E. (2006). Transformational and transactional leadership effects on teachers' job satisfaction, organizational commitment, and organizational citizenship behavior in primary schools: The Tanzanian case. School Effectiveness and School Improvement, 17, 145-177. https://doi.org/10.1080/09243450600565746

Porter, L. W., Steers, R. M., Mowday, R. T., \& Boulian, P. V. (1974). Organizational commitment, job satisfaction, and turnover among psychiatric technicians. Journal of Applied Psychology, 59(5), 603-609. https://doi.org/10.1037/h0037335

Rosenholtz, S. (1989). Teachers' workplace. The social organization of schools. New York: Longman.

Sheldon, M. E. (1971). Investment and involvement as mechanisms producing commitment to the organization. Administrative Science Quarterly, 16, 142-150. https://doi.org/10.2307/2391824

Singh, K., \& Billingsley, B. S. (1998). Professional support and its effect on teachers' commitment. The Journal of Educational Research, 91, 229-239. https://doi.org/10.1080/00220679809597548

Somech, A. (2005). Directive versus participative leadership: Two complementary approaches to managing school effectiveness. Educational Administration Quarterly, 41, 777-800. https://doi.org/10.1177/0013161X05279448

Steers, R. M. (1977). Antecedents and outcomes of organizational commitment. Administrative Science Quarterly, 22, 46-56. https://doi.org/10.2307/2391745

Stevens, J. M., Beyer, J. M., \& Trice, H. M. (1978). Assessing personal role and organizational predictors of 
Werang, B. R., \& Pure, E. A. G.

managerial commitment. Academy of Management Journal, 21, 380-396.

https://doi.org/10.2307/255721

The Kotton Mouth Kings [KMK] Team. (2014). The high cost of low employee commitment. Retrieved from http://www.kmaconsultingllc.com/the-high-cost-of-low-employee-commitment

Uncen-Unipa-Smeru-BPS-Unicef. (2012) 'We like being taught'. A Study on Teacher Absenteeism in Papua and West Papua. Retrieved from https://www.google.co.id/?gws_rd=cr,ssl\&ei=IKxsVsrdF8ekuQSU5JXYBA\#q=we+like+being+taught+ a+study+on+teacher+absenteeism+in+papua+and+west+papua

WBI Evaluation Group. (2007). Fishbone diagram. Retrieved from http://www.isixsigma.com/tools-templates/cause-effect/cause-and-effect-aka-fishbone-diagram/

Webrecruit Ireland. (2015). 5 Characteristics of a committed employee. Retrieved from http://www.webrecruitireland.com/employer.../5-characteristics-of-a-committed-employee

Werang, B. R. (2010). Teacher's profession. Malang: Elang Mas. (Indonesian: Profesi Keguruan).

Werang, B. R., Betaubun, M., \& Pure, E. A. P. (2015). Factors influencing teachers' organizational commitment (Case study on primary schools' teachers in remote area of Merauke regency, Papua, Indonesia). Journal of Educational Policy and Entrepreneurial Research, 2(10), 122-130

Werang, B. R., Leba, S. M. R., \& Betaubun, M. (2014). Alternative strategy for improving the quality of graduates in East Indonesia border area (Case study on State Senior High Schools Graduates in Merauke Regency). International Journal of Education and Research, 2(4), 245-252.

Werang, B. R., Leba, S. M. R., \& Pure, E. A. G. (2016). Factors influencing teacher absenteeism in the remote elementary schools of Indonesia: Empirical proof from southern Papua. International Journal of Management in Education, in press.

William, M. K. (2011). Motivation and job commitment among teachers in four selected senior high schools in the Ashanti region of Ghana (Unpublished masteral thesis). Institute of Distance Learning, Kwame Nkrumah University.

Wolowska, A. (2014). Determinant of organizational commitment. Human Resources Management \& Ergonomics, 8(1), 129-146. 